\title{
(Anti-)cliticization in Mapudungun
}

\author{
Fernando Zúñiga
}

Received: 24 March 2014 / Accepted: 4 October 2014 / Published online: 14 October 2014

(C) Springer Science+Business Media Dordrecht 2014

\begin{abstract}
This article describes the formal behavior of some elements found in Mapudungun (isolate, South America): a question particle, a postposition, and several 3rd-person markers. Framed in terms of current theories of phonological and grammatical words, the paper argues that a useful characterization of the Mapudungun elements under scrutiny should acknowledge (a) that clitics are interestingly heterogeneous regarding how different bound elements stand in paradigmatic opposition to each other, and (b) that some of these elements can be meaningfully be called anti-clitics (i.e., they are p-words that are part of larger g-words).
\end{abstract}

Keywords Clitic $\cdot$ Anti-clitic $\cdot$ p-word $\cdot$ g-word $\cdot$ Mapudungun

\section{Introduction $^{1}$}

Mapudungun is an unclassified language spoken by around 250,000 people in southcentral Chile and west-central Argentina. Fluency rates seem to be declining in younger generations, albeit not too sharply; the highest concentrations and/or numbers of fluent speakers are found among (elderly) adults living in rural, or at least nonmetropolitan, areas in the Bío-Bío and Araucanía Regions (Chile). The present study concentrates on the variety called Central Mapudungun, mainly spoken in Araucanía. Unless otherwise specified, data come from my own field notes. The orthographic convention used here for rendering Mapudungun data is the so-called Alfabeto Mapuche Unificado.

\footnotetext{
${ }^{1}$ I am indebted to Rik van Gijn for numerous and valuable comments to a previous version of this article.

F. Zúñiga (ه)

Department of Linguistics, University of Bern, Länggassstrasse 49, 3012 Bern, Switzerland

e-mail: fernando.zuniga@isw.unibe.ch
} 
The morphological-typological profile of Mapudungun is not rare in the Amerindian context. With respect to synthesis, the verbal domain is polysynthetic, the nominal domain is mildly synthetic, and other domains are analytical. (Here, polysynthesis means productive nominal incorporation, systematic verb stem serialization, and a relatively large number of potential affixal slots on verbs.) With respect to the technique parameters, the largely agglutinative morphology can be more precisely classified as concatenative, of predominantly separative exponence (i.e., polyexponential morphemes and portmanteaus are rare), and without flexivity (i.e., allomorphy is found in some inflectional phenomena, but it is almost exclusively phonologically conditioned). Basically suffixing and (clause-)head-marking, Mapudungun shows constituent order patterns that reflect both syntactic and pragmatic sensitivity: typical clauses are of the $\mathrm{V}(\mathrm{S})$ type, especially in narrative texts, but VS, VO and SVO clauses are also found, the latter type especially in elicitation.

The stress rules of Mapudungun are important for the present paper, so the basics are outlined in what follows. Disyllables in isolation are stressed depending on syllable structure (with closed syllables attracting stress), e.g. rúka 'house', máñke 'condor', pewén 'monkey puzzle tree', and tralkán 'thunder'. Monomorphemic trisyllables have secondary stress on the antepenult, e.g. àchawáll 'hen'. Plurisyllabic verb forms are usually somewhat more complex, with some inflectional suffixes attracting stress, and words in actual phrases behave according to more intricate patterns that are not well understood yet. See Zúñiga (2006:63f) for more details. ${ }^{2}$

Armed with a simple and reasonably mainstream typology of clitics (Sect. 2), the present paper analyzes three different kinds of elements that appear appended to other elements in Mapudungun and have received comparatively little attention from a form-oriented perspective in the literature. (In fact, neither cliticization in particular nor wordhood in general are topics treated in great detail in Mapudungun studies.) Section 3 deals with the question particle am, Sect. 4 addresses adpositions, paying special attention to the postposition mew, and Sect. 5 presents different 3rd person markers that show interesting properties against the background of any theory of wordhood. Section 6 summarizes the findings and gives some conclusions. The paper argues that, like with most natural-language phenomena that are approached theoretically and typologically with a simple but powerful analytical toolkit, it is the intermediate and hard-to-capture cases that are particularly interesting. For Mapudungun, this amounts to acknowledging that not all clitics, or their mirror images ("anti-clitics"), are equal, and that characterizing precisely such elements in more detail leads to a better understanding of how the morphosyntax of this Amerindian language, as well as morphosyntax in general, really works.

\footnotetext{
${ }^{2}$ My own observations coincide with the ones presented originally by Adalberto Salas in Salas (1978) and later in Salas (2006:73-75). These are largely compatible with Smeets (2008:49-50), who also makes crucial reference to the right edge of the phonological word, but incompatible with Echeverría and Contreras (1965) (the sole source for e.g. Goedemans and Van der Hulst 2013), who describe a stress pattern centering on the left edge of the word.
} 


\section{Typologies of clitics}

Most widespread notions of clitic revolve around the notion of autonomy. Prototypical words are autonomous both syntactically and phonologically, while prototypical affixes are dependent, i.e. non-autonomous, in both respects. Many current scholars see prototypical clitics as syntactically autonomous but phonologically dependent (i.e., they are g-words in their own right but part of a larger p-word, cf. Aikhenvald 2002).

A number of subtypes of such intermediate elements have been proposed in the literature. One of the most popular taxonomies distinguishes between simple and special clitics, based on whether such dependent elements behave according to the default syntactic rules of the language or not (cf. Halpern 1998; Zwicky 1977, 1985; Zwicky and Pullum 1983; but see Anderson 2005 for a critique of simple clitics and Bermúdez-Otero and Payne 2011 for one of special clitics). According to Kroeger's (2005:322f) systematization, simple clitics are further subdivided in bound words like the reduced auxiliaries of English (e.g. I've, he's) and Indonesian =nya ' $3 \mathrm{sG'} \mathrm{(cf.}$ Cohn 1989) on the one hand and phrasal affixes like English "genitive 's" (e.g. the Queen of England's cat) on the other. Special clitics also come in two well-known guises: verbal clitics (e.g. Romance person markers like la 'her' in Spanish la quiero $v e r=$ quiero verla 'I want to see her') and second-position clitics (e.g. the Russian polar question marker $l i$ and Czech person markers like $j i$ 'her' in vidím $j i$ 'I see her' and dnes ji vidim 'I see her today'). Further special clitics include floating clitics (like Latin interrogative ne in hicne vir usquam nisi in patria morietur? 'shall this man die anywhere but in his native land?') and clause-final clitics (like the Iquito enclitic na, which marks finite subordinate clauses, cf. Beier 2004).

In a recent study, Spencer and Luís (2010) see words and affixes as polar opposites and work with a canonical definition, according to which clitics are formally like a canonical affix (i.e., they are prosodically unspecified and dependent on another element and consist of a monomoraic CV syllable) but distributionally like a canonical function word (i.e., they occur at the edge of the phrase-rather than a word - that is its morphosyntactic domain and have wide scope over coordinated phrases). This naturally allows for a number of non-canonical elements that show properties of clitics and affixes in varying degrees. Second-position clitics, e.g., are like canonical clitics with respect to form but show a distribution pattern of their own. The same applies, according to Spencer and Luís, to French definite articles, Turkish verb inflections, and Polish floating/mobile inflections (e.g. $=m$ ' $1 \mathrm{SG}$ ' and $=$ s $m y$ ' $1 \mathrm{PL}$ '), all of which are formally like canonical clitics but distributionally different from them, and different from each other.

Summing up, some of the parameters along which subtypes of clitics differ are syntagmatic while others are paradigmatic. The former include host selectivity, host type, position in the word/phrase/clause, and phonological cohesion values; the latter include whether they belong to a particular part of speech and whether they alternate with other elements like suffixes or words. ${ }^{3}$ In a spirit similar to Spencer and

\footnotetext{
${ }^{3}$ Aikhenvald (2002) lists these and other formal properties, as well as some functional properties, including segmental properties, degree of cohesion, combinability with other clitics, scope, and lexicalization.
} 
Luís's, Van Gijn and Zúñiga (2014) propose four parameters for the classification of morphological units: (i) phonological integration (yes/partial/no), (ii) positional rigidity (yes/no), (iii) host sensitivity to syntactic weight (yes/no), and (iv) host sensitivity to lexical category (yes/no). I will try to ascertain such properties in order to characterize different elements in Mapudungun that are candidates for clitichood in Sects. 3 through 5. Note in passing that the criticisms mentioned in Haspelmath (2011) with respect to the notion of grammatical or (morpho-)syntactic word as a crosslinguistically valid notion do not apply here because the analysis is explicitly language-specific. Mapudungun-specific p-words and g-words will be assumed to exist as separate from smaller (feet and morphemes) and larger units (phrases) in what follows; a justification of such an assumption lies beyond the scope of the present paper.

\section{The question particle am}

Mapudungun particles have not been the object of much attention in the older literature on the language, and Smeets (2008:Chap. 32) is the only study I am aware of that addresses them systematically, albeit sketchily. Not only are the contexts of occurrence and exact functions of these elements still poorly understood, but very little is also found on their formal characteristics. The present section will outline the basics of the particle am with respect to form and function in interrogative sentences. ${ }^{4}$

The examples in (1) illustrate its use with question words $(\mathrm{a}-\mathrm{c})$ and in polar questions (d). ${ }^{5}$ Smeets says that $a m$ is employed here "to ask for more precise information, to express surprise or to provoke" (Smeets 2008:330). As usual in comparable cases in other languages, am is not strictly obligatory but often regarded by speakers as making (some) questions more idiomatic. Approximate translational equivalents seem to be German denn or etwa and Spanish acaso; in English, really seems to cover part of its functions.

am 'Q' (Smeets 2008:330-331, Augusta 1916:76)

a. Chumngechi am dewmayafin?

chumngechi=am dewma- $a-f i-n$

how $=\mathrm{Q}$ make-FUT-3.OBJ-1SG.SBJ.IND

'How shall I make/finish it?' (a question to the person in charge)

(cf. chumngechi Ø dewmayafin — the speaker wonders to him/herself)

\footnotetext{
${ }^{4}$ This particle (or its allomorph $\mathrm{kam}$ ) also occurs in affirmative sentences, sometimes with a clear causal function (e.g. amulayan iñche, füchalu kam [I.will.not.go 1SG get.old.PCPL PART] 'I will not go, because I am [too] old') and on occasion with a focus-like yield (eymi kam müten [2SG PART only] 'it is only up to you (SG)') (Augusta 1916:76). A similar semantic connection is found in Germanic: High German denn and dann alternated more or less freely until the 18th century (now, denn means 'because, than' and also occurs as an interrogative particle, and dann means 'then'). The German elements are cognates of English then and than, which also alternated freely until ca. 1700.

${ }^{5}$ The same am seems to occur in compound particles as well (as enclitic in chiam $<$ chi $=a m$ and as proclitic in anta $<a m=t a$ and $a n c h i<a m=c h i)$, but such elements, as well as their building blocks $c h i$ and especially $t a \sim \underline{t} a$, are even more poorly understood (cf. Smeets 2008:335f).
} 
b. Chem mew am femllenuafulu? chem mew =am fem-lle-nu-a-fu-lu what $\mathrm{POSTP}=\mathrm{Q}$ do.so-CERT-NEG-FUT-RI-PTCP

'Why shouldn't [they] have done that?' ("of course they did!')

c. Fey chumal am rekülamapafimi?

fey chum-a-el=am rekülama-pa-fi-i-m-i

then be.what-FUT-NFIN $=\mathrm{Q}$ claim-CIS-3.OBJ-IND-2-SG

'Then what have you (SG) come to claim it for?'

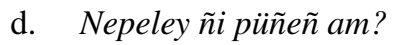

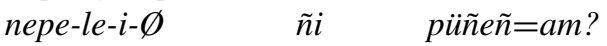

wake.up-RES-IND-3 1SG.PSR child.of.woman $=\mathrm{Q}$

'Is my child awake?' (asks the mother, hearing sounds in the house)

Am attaches at the end of a constituent and actually attracts primary stress — simply following the stress allocation rules of the language: it is (part of) a final closed syllable. The reasons to say that it attaches to a host are two: (i) it never occurs as an isolated utterance, or after a pause, and (ii) together with the preceding element, it forms a new p-word for purposes of stress (cf. chumal [tu'mal] vs. chumal am [tuma'lam] in (1c)). There seems to be a clear tendency for am to occur immediately after the question word (which can be plurimorphemic, as chem mew 'why' (lit. 'for what') in (1b)) and clause-finally in polar questions. Although the issue merits exploration in more detail, my data suggest that complex interrogative sentences strongly disfavor am-marking. In diminishing order of preference, the admissible possibilities are only simple main clause and subordinate clause followed by am-marked main clause. Speakers are clearly more than uncomfortable with attempts to have $=a \mathrm{~m}$ appear at the end of a subordinate clause following a main clause, and I have not found such cases in published texts.

The element am has no free-standing counterpart, nor a clear part of speech it might be assigned to. It might be regarded as simultaneously host-neutral and positionally free (i.e., as a phrasal affix), but this would neglect the fact that its occurrence with polar and nonpolar questions seems to be in systematic complementary distribution. With respect to Spencer and Luís's canonical approach, am is prosodically dependent but does not conform to the $\mathrm{CV}$ canon and is therefore not entirely formally canonical; nevertheless, it is distributionally canonical (at the edge of its relevant phrase, which is different for polar and nonpolar questions, and showing wide scope).

\section{Adpositions}

The prepositions most commonly used in the language are the ones listed in (2): ${ }^{6}$

\footnotetext{
${ }^{6}$ I am glossing over several details here, e.g. there is a homonymous adnominal plural marker $p u$, ina also occurs as a verb root meaning 'follow, chase', and wente and miñche are originally adverbs and used to cooccur with mew (see further down in the main body of text). See Augusta (1903:128f) for other prepositional elements.
} 
(2) Prepositions
a. $p u$ 'in'
e.g. pu ruka
(in house)
'in the house'
b. ina 'next to'
e.g. ina rüpü
(next.to road)
'next to the road'
c. wente 'on'
e.g. wente mesa
(on table)
'on the table'
d. miñche 'under'
e.g. miñche ruka
(under house)
'under the house'

Prepositions form a closed lexical class and are positionally restricted: they always appear before an NP, which minimally consists of a simple noun root or a personal pronoun but can be as complex as a multiradical nominal with derivational suffixes and preceded by adjectives, demonstratives, articles, and an embedded possessor NP. Prosodically, they can be the most prominent element of the PP only in the context of contrastive focus. They do not appear in a reduced form but have both a proclitic and an autonomous form.

The postpositions most commonly found are given in (3), viz. püle 'toward' (a), kütu 'from' (b), and the semantically unspecified mew (c): ${ }^{7}$

\section{Postpositions}

a. lafken mapu püle

sea land toward

'toward the coast'

b. tüfa kütu Troltren fentren mapu

this from $\mathrm{T}$. as.far.as land

'from here to Toltén'

c. - Troltren (mew) amuan

T. POsTP I.will.go

'I will go to Toltén'

- Troltren (mew) küpan

T. POSTP I.came

'I came from Toltén'

- Anton ñi furi mew

A. 3.PSR back POSTP

'behind Antonio'

- Aneltufiñ kiñe kuchillo mew. aneltu-fi-n

kiñe kuchillo mew

threaten-3.OBJ-1SG.SBJ.IND one knife POSTP

'I threatened him with a knife.'

Like prepositions, postpositions form a closed lexical class and are positionally restricted: they always appear after an NP. Prosodically, they can be the most prominent element of the PP only in the context of contrastive focus-which seems to be significantly less common than with prepositions. They appear in either a full or a

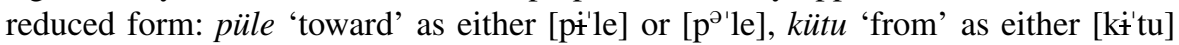
or $\left[\mathrm{k}^{\partial} \mathrm{tu}\right] \sim[\mathrm{ktu}]$, and mew as either $[\mathrm{mew}]$ or $[\mathrm{mo}] \sim[\mathrm{mu}] .{ }^{8}$ Note that, unlike the former two adpositions, mew does not have a disyllabic variant. This is relevant for

\footnotetext{
${ }^{7} \mathrm{Mew}$ is often omitted as syntactic licenser of location/source/goal NPs with motion or posture verbs.

${ }^{8}$ Smeets (2008:61f) labels mew mu as "instrumental case suffix."
} 
the stress placement rules, as shown in the variation illustrated in (4); since the unit consists of one syllable, it can attract stress when closed (mew) but usually does not when open $(m o \sim m u)$ :

(4) The (morpho-)phonology of mew

a. chi rüpü mew 'on the road'

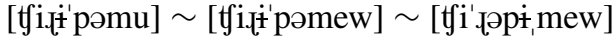

b. chi kuchillo mew 'with the knife'

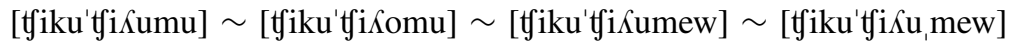
$\sim$ [tfiku'tfiאo, mew]

c. chi wentru mew 'for/to the man'

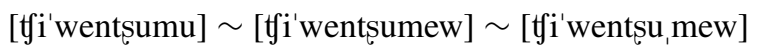

This postposition can be realized either as the final syllable of a new p-word or as a separate, non-prominent (i.e. secondarily stressed) p-word in its own right. In principle, the $[\mathrm{o}] \sim[\mathrm{u}]$ alternation can be seen as indicating a word boundary: word-final $/ \mathrm{o} /$ can be realized as $[\mathrm{u}]$ in allegro speech, as in wentro or wentru ['wentsu] 'man', but word-initial /o/ never is. (There are exceptions, like ko 'water', which is never reduced to $* k u$.) There is considerable variation, however; my consultants realized kuchillo 'knife' variably before mew (4c), but tended to consistently realize wentru with a final $u$.

I close this brief outline by concluding that Mapudungun adpositions in general, and the postposition mew in particular, have both a clitic and an autonomous form. Phonologically, proclitics seem to be a bit more autonomous (i.e. less reduced) than enclitics. As to their (non)canonical properties, the bound variants are positionally rigid and do appear at the edge of the relevant morphosyntactic domain (which can be either light or heavy NPs), but they do not show clear wide scope over coordinated NPs (e.g. ? kuchillo ka toki mew seems to be possible but dispreferred when compared to kuchillo mew ka toki mew 'with a knife and an axe').

\section{Selected 3rd person markers of Mapudungun}

This section covers two distinct phenomena. The first one is a set of markers of nonsingular 3rd person participants that occur with varying degrees of attachment to other elements, and the second is a marker mew - apparently homophonous with the postposition presented in the preceding section-that encodes 3rd person actors in inverse finite verb forms. The interest of such phenomena lies in the fact that they all index verbal arguments or possessors but show disparate formal and distributional properties that have not been coherently systematized in the literature. I will address them in turn.

\subsection{Nonsingular third person markers}

The three persons and three numbers distinguished in Mapudungun are most clearly seen on the personal and possessive pronouns listed in Table 1 below. The basic analysis of these forms is that there are four specialized stems (iñch- '1', ei- '2', distal 
Table 1 Personal and possessive pronouns in Mapudungun

\begin{tabular}{|c|c|c|c|}
\hline & Personal (preverbal) & Personal (postverbal) & Possessive \\
\hline $1 \mathrm{SG}$ & \multicolumn{2}{|c|}{ iñch-e > iñche } & $\tilde{\mathrm{n}} \mathrm{i}$ \\
\hline $1 \mathrm{DU}$ & \multicolumn{2}{|c|}{ iñch-i-u > iñchiw } & $\mathrm{i}-\mathrm{u}>\mathrm{yu}$ \\
\hline $1 \mathrm{PL}$ & \multicolumn{2}{|c|}{ iñch-i-n > iñchiñ } & i-n > iñ \\
\hline $2 \mathrm{SG}$ & \multicolumn{2}{|c|}{ ei-m-i > eymi } & $\mathrm{m}-\mathrm{i}>\mathrm{mi}$ \\
\hline $2 \mathrm{DU}$ & \multicolumn{2}{|c|}{ ei-m-u > eymu } & $\mathrm{m}-\mathrm{u}>\mathrm{mu}$ \\
\hline $2 \mathrm{PL}$ & \multicolumn{2}{|c|}{ ei-m-n > eymün } & m-n $>$ mün \\
\hline 3SG/3INAN & \multicolumn{2}{|c|}{ fey } & $\tilde{\mathrm{n}} \mathrm{i}$ \\
\hline 3DU.ANIM & fey+eng-u > feyengu & +eng-u > (y)engu & $\tilde{n} \mathrm{i} \_$engu \\
\hline 3PL.ANIM & fey+eng- $n>$ feyengün & +eng- $\mathrm{n}>$ (y)engün & $\tilde{n} \mathrm{i} \_$engün \\
\hline
\end{tabular}

demonstrative $f e y$, and $e$ - ' $\left.3 \mathrm{NSG}^{\prime}\right)^{9}$ and several inflectional suffixes $(-i$ ' 1 ', $-m$ ' 2 ', $-\varnothing$ ' 3 '; $-i$ 'SG', $-u$ 'DU', $-n$ 'PL'; the portmanteau forms $\tilde{n} i$ and $-e$ for the 1 st (and 3rd) persons are non-compositional). While possessive markers always precede their possessed nominal (cf. ñi ruka 'my/his/her house', or Juan ñi ruka 'Juan's house'), personal pronouns can either precede or follow the verb form to which they correspond; 3rd person nonsingular forms have preverbal and postverbal allomorphs. Interestingly enough, and contravening the default stress assignment rules in the language, the final $u$ on the $3 \mathrm{rd}$ person dual forms attracts stress. The symbol "+" in what follows represents a morpheme boundary unspecified for affixhood/clitichood status; the nature of such boundary will be the topic of discussion further down.

Mapudungun verb forms can be finite, marking at most two (bipersonal) and at least one participant (monopersonal) or nonfinite, which mark one participant less than their finite counterpart and have some restrictions as to their TAM inflectional potential. The suffixes marking person and number of the privileged syntactic argument or "subject" of finite forms are virtually identical to those marking those categories on pronouns, cf. Table 2 below; additionally, these forms take a mood marker ( $-i$ 'IND', $-l$ 'SUBJ', $\varnothing$ 'IMPER'). In such paradigms, the final $u$ on the 3 rd person dual forms attracts stress as well:

The examples in (5) below illustrate the typical use of pronouns and indicative verb forms. In (a), the 3 rd person possessive pronoun $\tilde{n} i$ is used with a nonsingular possessor whose referent is retrievable from the context; $\tilde{n} i$ chaw engu or $\tilde{n} i$ chaw engün would be used to explicitly express dual or plural possessors respectively. Personal pronouns are usually not necessary in main clauses and often only verb morphology expresses person (b). Nevertheless, personal pronouns can be added for focus/disambiguation purposes. In (c), the 3rd person dual object is indexed by $-f i$ on the (direct bipersonal) verb, which is unspecified for number, so the element engu can be encliticized to disambiguate. Similarly, in (d), the 3rd person dual subject is

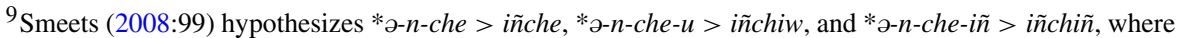
$*^{*} n$ is the 1 SG.IND marker $\left({ }^{*} n-c h>\tilde{n} c h\right)$, *ə is fronted (and raised) before $\tilde{n}$, and * che 'person' is equivalent to the current lexical item. In her view, the element $*_{e}$ in 2 nd person pronouns "is [also] probably related" to inverse $-e$. I remain unconvinced (but agnostic) with respect to these proposed etymologies.
} 
Table 2 Monopersonal verb forms in Mapudungun (underlying, simplified; tripa- 'exit')

\begin{tabular}{|c|c|c|c|}
\hline & Indicative & Subjunctive & Imperative \\
\hline $1 \mathrm{SG}$ & tripa-n $>$ tripan & tripa-li $>$ tripali & tripa-chi $>$ tripachi \\
\hline $1 \mathrm{DU}$ & tripa-i-i-u $>$ tripaiyu & tripa-1-i-u > tripaliyu & tripa- $\varnothing-\mathrm{i}-\mathrm{u}>$ tripayu \\
\hline $1 \mathrm{PL}$ & tripa-i-i-n $>$ tripaiyiñ & tripa-1-i-n > tripaliñ & tripa- $\varnothing-i-n>$ tripaiñ \\
\hline $2 \mathrm{sG}$ & tripa-i-m-i > tripaymi & tripa-l-m-i > tripalmi & tripa-nge $>$ tripange \\
\hline $2 \mathrm{DU}$ & tripa-i-m-u > tripaymu & tripa-l-m-u > tripalmu & tripa- $\varnothing-\mathrm{m}-\mathrm{u}>$ tripamu \\
\hline $2 \mathrm{PL}$ & tripa-i-m-n > tripaymün & tripa-1-m-n > tripalmün & tripa- $\varnothing-m-n>$ tripamün \\
\hline \multirow[t]{2}{*}{$3 \mathrm{SG}$} & tripa-i- $\varnothing$ & tripa-le & tripa-pe \\
\hline & $>$ tripay $^{\mathrm{a}}$ & $>$ tripale & $>$ tripape \\
\hline \multirow[t]{2}{*}{$3 \mathrm{DU}$} & tripa-i+ng-u & tripa-1+ng-u & tripa-pe+eng-u \\
\hline & $>$ tripaingu & $>$ tripalngu & $>$ tripape yengu \\
\hline \multirow[t]{2}{*}{ 3PL } & tripa-i+ng-n & tripa-1+ng-n & tripa-pe+eng-n \\
\hline & $>$ tripaingün & $>$ tripalngün & $>$ tripape yengün \\
\hline
\end{tabular}

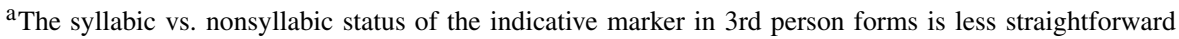
than the spelling conventions $-i$ and $-y$ may suggest. (And there is considerable variation as to how glides are orthographically rendered in Mapudungun studies.) Postvocalically and verb-finally, the indicative morpheme is always realized nonsyllabically (e.g. tripa- $i>$ tripay 's/he exited'; after $i$ it is simply deleted, e.g. $p i-i>p i$ 's/he said'). If the preceding segment is a consonant or a glide, it is always the nucleus of the word-final syllable (e.g. kon-i > koni 's/he entered', küdaw-i > küdawi 's/he worked'). Salas (2006:88f) explicitly says that " $y$ turns to $i$ before engu or engün" in tripay, but the same source notes the fact that an alternative pronunciation is possible as well: even though four-syllable [tsi.,pa.i.'nu] is probably the default realization, three-syllable [tsi.,pai.' 'yu] is also available in allegro speech (the stress pattern indeed suggests that it is a reduced form). The fact that $i$ does become nonsyllabic before either 2 nd person $m$ or 3 rd person mew (cf. Sect. 5.2) suggests that the appended elements may have an underlying/etymological $e$ and do not/did not start with $n g$

marked by a zero on the verb, which is unspecified for number in inverse bipersonal forms, so the corresponding enclitic engu is appended. ${ }^{10}$ Interestingly, (e) shows that such enclitics are not strictly verbal; rather, they appear clause-finally. Lastly, a preverbal pronoun can be seen in (f).

Indicative verb forms and pronouns/NPs (Salas 2006:Latrapay.2-3; Smeets 2008:98)

a. Mongelekefuy ñi chaw.

monge-le-ke-fu-i-Ø $\tilde{n} i \quad$ chao

live-PROG-HAB-RI-IND-3 3.PSR father

'Their father was alive then.'

b. Kuñifallngeingu.

kuñifall-nge- $i+n g-u$

abandon-PASS-IND+3NSG-DU

'They were both left behind/abandoned.'

${ }^{10}$ See Zúñiga (2006:Chap. VII) for a detailed account of direct and inverse verb forms in Mapudungun. 
c. Lelifiñ engu.

leli-fi-n+eng-u

look.at-3.OBJ-1SG.SBJ.IND+3NSG-DU

'I watched the two of them.'

d. Fey ta ngünayekefeyew engu.

fey $\quad \underline{t} a$

DEM[SG] PART

ngüna-ye-ke-fu-e-i-Ø-mew+eng-u

protect-DISTR-HAB-RI-INV-IND-3.SBJ-3.OBJ+3NSG-3DU

'This [one] used to protect them both.'

e. Anümkay pinu yengün.

anü-m-ka-i- Ø pinu+eng-n

sit.down-CAUS-CONT-IND-3 cane+3NSG-PL

'They (PL) planted cane.'

f. Feyengu akuingu.

Fey+eng- $u \quad a k u-i+n g-u$

DEM+3NSG-DU arrive.here-IND+3NSG-DU

'They (DU) arrived here.'

g. Akuy (*ngu) epu wentru.

$a k u-i(-\varnothing)+n g-u$

ерu wentro

arrive.here-IND-3+3NSG-DU two man

'Two men arrived here.'

Observe in $(5 \mathrm{~g})$ above that lexical nonsingular 3rd persons are in complementary distribution with the verbal marking: both akuy ерu wentru 'two men arrived here' and akuingu 'they both arrived here' are possible, but *akuingu epu wentru is not. With pronominal 3rd persons, there is some variation; feyengu akuingu seems to be clearly preferred to feyengu akuy (5f above) (which is also possible); in the plural both feyengün akuingün and feyengün akuy seem to be roughly equally acceptable. Note in this context the following examples from Salas (2006:222-223):

(6) (Piwi ta epu kuñifall wentru. Amutuingu.)

('[Thus] the two poor men said to each other. Both of them went away.)

Amuingu ka powi kiñe fütra witrulku mew engu.

amu-i+ng-u ka pow-i- $\quad$ kiñe fütra

go-IND+3NSG-DU and arrive.there-IND-3 one big

witrulku mew + eng-u

brook POSTP+3NSG-DU

'They (DU) set off and arrived at a big brook.'

The lexical NP ери kuñifall wentru 'two poor men' establishes reference, number, and other features of the main participants in a preceding clause; the next clause (amutuingu 'they (DU) went away' shows the expected number marker on the verb). The first verb form of the last clause (amuingu 'they (DU) went') carries the 3rd person dual marker, whereas the second verb form (powi 'X arrived there') is unmarked for number; the 3DU marker engu comes at the very end of the clause, in its postverbal form as expected. 
A further use of the personal pronoun is to mark accompaniment, as shown in (7). ${ }^{11}$ Unsurprisingly, the form engu is used for two participants (a) and engün is used with more than two (b):

"Comitative use" of the personal pronoun (Smeets 2008:139-140; Salas 2006:90)

a. Alü kamapuley Peru engu Argentina.

alü kamapu-le-i- $\varnothing \quad$ Peru eng-u Argentina

much far.away-RES-IND-3 P. 3NSG-DU A.

'Peru and Argentina are far away.'

b. Kom ñi pu che engün kañpüle amuy.

kom ñ puche eng-n kañpüle amu-i-Ø

all 3.PSR PL person 3NSG-PL elsewhere go-IND-3

'He went elsewhere with his entire family.'

c. Antonio amuay Temuko ñi pu karukatu engün.

Antonio aтu-a-i-Ø Temuko ñi pu karukato eng-n

A. go-FUT-IND-3 T. 3.PSR PL neighbor 3NSG-PL

'Antonio will go to Temuco with his neighbors (PL).'

The synchronic description of these nonsingular 3rd person markers has to distinguish several kinds of markers due to their formal make-up and distribution. I use Van Gijn and Zúñiga's (2014) systematization in Table 3 (also referring to Spencer and Luís's 2010 scope parameter in the text below).

The $-n g u \sim-n g u ̈ n$ markers on indicative and subjunctive verb forms qualify as canonical affixes and are actually treated as affixes in the literature on Mapudungun; they show maximal cohesion with their host, which cannot but be a finite verb form, and they do not show wide scope even although they stand in something of a complementary distribution with lexical NPs. Most other elements resemble function words regarding their form: they are more autonomous and not reduced. Nevertheless, not all of them conform to the canonical function-word pattern regarding their distribution. The nonadjacent postverbal personal pronoun would come closest to wordhood (evidence is inconclusive at this point; some speakers prefer one such element per verb form, with some tendency towards appending it to the predicate, while othersperhaps most - treat such elements as more loosely attached); Mapudungun studies have commonly treated them as "pronouns," i.e., as separate words. The possessor explicator behaves mostly alike (? $\tilde{n} i \tilde{n} u k e$ ka ñ chaw engu [3.PSR mother and 3.PSR father 3DU] 'their (DU) mother and father' is possible in principle but strongly dispreferred; alternatives like $\tilde{n} i \tilde{n} u k e$ engu ka ñi chaw engu or feyengu $\tilde{n} i \tilde{n} u k e ~ k a ~ \tilde{n} i$ chaw are favored by speakers), but it must follow an NP. The coordinating postposition attaches to an NP but does not show wide scope, i.e., it has to be repeated after each coordinated element. Most interestingly, the imperative 3NSG markers and the element appended to the demonstrative are affix-like with respect to their distribution (lexical host selectivity and narrow scope), but they seem to retain considerable formal autonomy. Observe that only the imperative 3NSG markers can optionally take

${ }^{11}$ Augusta (1903:128f) treated such elements as equivalent to Spanish con 'with', i.e., as "prepositions." 
Table 3 Selected properties of nonsingular 3rd person markers (e.g. . . ng- $u$ '3DU’)

\begin{tabular}{|c|c|c|c|c|}
\hline & $\begin{array}{l}\text { Phonological } \\
\text { integration }\end{array}$ & $\begin{array}{l}\text { Positional } \\
\text { rigidity }\end{array}$ & Syntactic weight & Lexical class \\
\hline $\begin{array}{l}\text { Nonimperative finite marker: } \\
\text { amutuingu 'they (DU) went } \\
\text { away' }\end{array}$ & $\checkmark$ & $\checkmark$ & $\checkmark$ & $\checkmark$ \\
\hline $\begin{array}{l}\text { Nonadjacent postverbal } \\
\text { marker: } \\
\text { amutuy ... engu 'they (DU) } \\
\text { went away' }\end{array}$ & $x$ & $\checkmark$ & $x$ & $x$ \\
\hline $\begin{array}{l}\text { Possessor explicator: } \\
\text { ñi chaw engu 'their (DU) } \\
\text { father' }\end{array}$ & $x$ & $\checkmark$ & $x$ & $\checkmark$ \\
\hline $\begin{array}{l}\text { Coordinating postposition: } \\
\text { Chile engu Peru 'Chile and } \\
\text { Peru' }\end{array}$ & $x$ & $\checkmark$ & $\checkmark$ & $x$ \\
\hline $\begin{array}{l}\text { Imperative finite marker: } \\
\text { tripape (y)engu 'may they } \\
\text { (DU) exit' }\end{array}$ & $(\checkmark)$ & $\checkmark$ & $\checkmark$ & $\checkmark$ \\
\hline $\begin{array}{l}\text { Preverbal pronoun: } \\
\text { feyengu amutuy 'they (DU) } \\
\text { went away' }\end{array}$ & $(\checkmark)$ & $\checkmark$ & $\checkmark$ & $\checkmark$ \\
\hline
\end{tabular}

a connecting glide $y$ if the preceding segment is a vowel. Furthermore, stress patterns differ, suggesting that the imperative 3 NSG markers, but not adnominal engu engün, are part of one p-word; the latter are stressed themselves and do not change the stress of the preceding (or following) word (e.g., rúka 'house', máñke 'condor', pewén 'monkey puzzle tree', and tralkán 'thunder' will normally retain their stress before/after engu or engün). The imperative 3NSG markers, by contrast, do change the stress pattern (e.g., pínu ['pinu] 'cane', with a stressed penult, normally becomes pinù yengú [pi,nuye'ju], with secondary stress on the antepenult and primary stress on the ultima in (5e) above).

This leaves us with an interestingly complex picture. Nonsingular 3rd person markers are located along a multidimensional continuum of phonological and distributional properties: between the two poles of affixal and (almost fully) word-like markers, we find possibly two distinct non-canonical types of non-autonomous elements. Both resemble function words regarding form but are either like French definite articles or like affixes regarding distribution.

\subsection{Third person actor marker with inverse finite verb forms}

Mapudungun transitive verbs can appear in direct and inverse forms. Roughly, the former are used when 1 st or 2 nd persons act on 3 rd persons, or when a more prominent 3rd person acts on a less prominent one; the latter are employed when a 3rd person acts on a speech act participant, or when a less prominent 3rd person acts on a more prominent one. Finite inverse forms, therefore, mark two persons: the prominent (patientive) one, distinguishing both person and number (the "subject"), and the 
less prominent (agentive) one, which is simply 3rd person (the "object"). In addition, these inverse forms take the suffix $-e$; an indicative paradigm with $p i$ - 'say, tell' can be seen in (8) below. Note that those with singular subjects lose some segments in their surface forms; mew turns to ew with $1 \mathrm{SG}$ and $3 \mathrm{SG}$, and the sequence mimew is reduced to mew with $2 \mathrm{sG}$ :

$$
\begin{aligned}
& \text { Verbal mew (with inverse indicative forms of } p i \text { - 'say, tell') } \\
& 3 \rightarrow 1 \mathrm{SG} \text { pi-e-n-mew }>\text { pienew } \\
& 3 \rightarrow 1 \mathrm{DU} \text { pi-e-i-i-u-mew }>\text { pieyumew } \\
& 3 \rightarrow 1 \mathrm{PL} \text { pi-e-i-i-n-mew> pieiñmew } \\
& 3 \rightarrow 2 \mathrm{SG} \text { pi-e-i-m-i-mew }>\text { pieymew } \\
& 3 \rightarrow 2 \mathrm{DU} \text { pi-e-i-m-u-mew }>\text { pieymumew } \\
& 3 \rightarrow 2 \mathrm{PL} \text { pi-e-i-m-n-mew }>\text { pieymünmew } \\
& 3 \rightarrow 3 \mathrm{SG} \text { pi-e-i-Ø-mew }>\text { pieyew }
\end{aligned}
$$

Similar reductions occur with most singular subjects in the subjunctive and with all (unmarked) subjects in some nonfinite forms. ${ }^{12}$

Thus, the element encoding 3rd person actors-objects on inverse verbs is $(\mathrm{m}) \mathrm{ew} .{ }^{13}$ Even though inverse - $e$ attracts stress in some, but not all, of these forms, this $(m) e w$ is best analyzed as a verbal suffix. Even if it were a cognate of the postposition presented in Sect. 4, it differs from it rather markedly both in formal and functional terms. In Spencer and Luís's terms, this mo ти qualifies as canonical affix; its non-strictly$\mathrm{CV}$ allomorph mew is almost canonical.

\section{Summary and conclusions}

The present paper outlined some parameters of the formal make-up and behavior of three functionally different dependent elements, viz. the interrogative marker am, a number of adpositions, and several 3rd person indexes. In terms of the typology sketched in Sect. 2, am is a simple clitic of the phrasal affix subtype, a next-tocanonical clitic; it is probably best to assign particle status to it, and it has no counterpart that differs from it in either form or distribution. The semantically unspecified postposition mew, by contrast, is a function word that can occur (occasionally, or dialectally, reduced to $m u$ ) as a simple clitic of the bound word subtype, or as a noncanonical clitic. The indexes of 3rd person participants are more varied. Glossing over the details of how dependence is parameterized merely for the sake of expository clarity, the overall picture is schematically summarized in Table 4.

\footnotetext{
${ }^{12}$ Singular subject subjunctive inverses are $3 \rightarrow 2 \mathrm{SG}$ pi-e-l-m-i-mew $>$ pielmew (instead of *pielmimew), $3 \rightarrow 3 \mathrm{SG}$ pi-e-le-mew $>$ pieliyew (instead of * pielemew), and nonreduced $3 \rightarrow 1 \mathrm{SG}$ pi-e-li-mew $>$ pielimew. Nonfinite forms replace the mood-person-number sequence of finite forms with a nonfinite ending like $-n$, $-e l,-a m,-l u$, etc. It appears plausible to reconstruct the inverse nonfinite counterpart -etew of direct -el as $*_{-}$-et-mew, consisting of the inverse marker $*_{-} e$, the nonfinite marker $*_{-} e t$ (which appears as -el wordfinally, by a general rule that precludes syllable-final plosives from appearing in the language), and the 3rd person actor marker *-mew.

${ }^{13}$ Eastern varieties of Mapudungun, which have $m u$ as the default realization of the postposition, also have $(m) u$ as the default realization of this marker.
} 
Table 4 Selected Mapudungun elements and their properties
Formal dependence
Formal independence

Distributional

dependence

Distributional independence
Affixes:

- nonimperative $-n g-\{\mathrm{NUM}\}$

- verbal -mew $\sim-m u$

Clitics:

- interrogative $=a m$

- postposition $=m e w \sim=m u$
"Anti-clitics":

several 3NSG markers

Words:

- postposition mew

- nonadjacent postverbal eng- $\{\mathrm{NUM}\}$

- possessor explicator eng-\{NUM $\}$

The preceding section gave a more detailed account of the several "anti-clitics" identified for Mapudungun, i.e. units that are probably best seen as (largely) independent p-words (or, at least, as units that do not interfere with the host p-word in terms of stress) but as parts of larger g-words. Dixon and Aikhenvald (2002:28) mention comparable elements in Yidiny, Jarawara, Georgian, and Turkish. To my knowledge, such elements have not been studied in great detail from a crosslinguistic perspective. Dixon's examples, Spencer and Luís's comments on French, Turkish, and Polish non-canonical clitics mentioned in Sect. 2 above, and some of the Mapudungun 3 NSG markers addressed in Sect. 5, however, suggest that any theory of cliticization in particular and of wordhood in general would benefit from exploring different parameters of formal and distributional dependence in similar phenomena on a wide basis. Binary approximations like dependence vs. independence are best replaced by fine-grained parameter sets like the ones used in Zwicky (1985), Aikhenvald (2002), Spencer and Luís (2010), and Van Gijn and Zúñiga (2014), in order to arrive at a more comprehensive picture. It is clearly an empirical question whether some, many, or even most of the most powerful parameters lead to robust clusters (cf. Haspelmath's 2011 critique of the crosslinguistically valid notion of g-word).

As far as the description of Mapudungun is concerned, the language does not seem to have special clitics of either the Romance-like verbal clitic type or the secondposition type. In fact, and even though clear cases of words and affixes exist, the elements discussed in this study suggest that several intermediate values of the dependence parameters are not only possible but perhaps also stable, with respect to both their (anti-)clitic quality and their non-canonicity (and non-prototypicality). Degrees of cohesion and kinds of cohesion are dimensions that need more in-depth explorations, both language-specifically and crosslinguistically, irrespective of the particular theory of wordhood that one would rather espouse.

Abbreviations and symbols ANIM animate, CAUS causative, CERT certainty, CIS cislocative, CONT continuative, DEM demonstrative, DISTR distributive, DU dual, FUT future, HAB habitual, IMPER imperative, INAN inanimate, IND indicative, INV inverse, NEG negation, NFIN nonfinite, NSG nonsingular, NUM number, OBJ object, PART particle, PASS passive, PCPL participle, PL plural, POSTP postposition, PROG progressive, PSR possessor, PTCP participle, Q question, RES resultative, RI ruptured implicature, SBJ subject, SG singular, SUBJ subjunctive 


\section{- $\quad$ affixation boundary \\ $=\quad$ cliticization boundary \\ \# prosodic word boundary \\ $+\quad$ unspecified morpheme boundary \\ $\{\mathrm{X}\}$ set of different values/forms for $x$ \\ $\mathrm{x} \rightarrow \mathrm{y}$ ' $x$ acting on $y$ '}

\section{References}

Aikhenvald, A. (2002). Typological parameters for the study of clitics, with special reference to Tariana. In R. M. W. Dixon \& A. Aikhenvald (Eds.), Word. A cross-linguistic typology (pp. 42-78). Cambridge: Cambridge University Press.

Anderson, S. (2005). Aspects of the theory of clitics. Oxford: Oxford University Press.

de Augusta, F. J. (1903). Gramática mapuche bilingüe. Santiago: Séneca. [1990].

de Augusta, F. J. (1916). Diccionario araucano: mapuche-español, español-mapuche. Santiago: Cerro Manquehue. [2007].

Beier, C. (2004). El marcador clítico de fin de cláusula -na. Ms., Iquito Language Documentation Project, University of Texas at Austin.

Bermúdez-Otero, R., \& Payne, J. (2011). There are no special clitics. In A. Galani, G. Hicks, \& G. Tsoulas (Eds.), Morphology and its interfaces (pp. 57-96). Amsterdam: Benjamins.

Cohn, A. (1989). Stress in Indonesian and bracketing paradoxes. Natural Language and Linguistic Theory, $7(2), 167-216$.

Dixon, R. M. W., \& Aikhenvald, A. (2002). Word: a typological framework. In R. M. W. Dixon \& A. Aikhenvald (Eds.), Word. A cross-linguistic typology (pp. 1-41). Cambridge: Cambridge University Press.

Echeverría, M., \& Contreras, H. (1965). Araucanian phonemics. International Journal of American Linguistics, 31, 132-135.

Van Gijn, R., \& Zúñiga, F. (2014). Word and the Americanist perspective. Morphology, September 2014.

Goedemans, R., \& van der Hulst, H. (2013). Fixed stress locations. In M. Dryer \& M. Haspelmath (Eds.), The world atlas of language structures online, Leipzig: Max Planck Institute for Evolutionary Anthropology. (Available online at http://wals.info/chapter/14, Accessed on 2013-12-12).

Halpern, A. (1998). Clitics. In: Spencer \& Zwicky (Eds.) (pp. 101-122).

Haspelmath, M. (2011). The indeterminacy of word segmentation and the nature of morphology and syntax. Folia Linguistica, 45(1), 31-80.

Kroeger, P. (2005). Analyzing grammar. An introduction. Cambridge: Cambridge University Press.

Salas, A. (1978). Mapuche-español. Análisis fonológico contrastivo. VICUS Cuadernos, Lingüística, II, 57-86.

Salas, A. (2006). El mapuche o araucano (2nd, revised ed.). Santiago: Centro de Estudios Públicos.

Smeets, I. (2008). A grammar of Mapuche. Berlin: de Gruyter.

Spencer, A., \& Luís, A. (2010). The canonical clitic. In D. Brown, M. Chumakina, \& G. Corbett (Eds.), Canonical morphology and syntax (pp. 123-149). Oxford: Clarendon Press.

Spencer, A. \& Zwicky, A. (Eds.) (1998). The handbook of morphology. Oxford: Blackwell.

Zúñiga, F. (2006). Mapudungun—el habla mapuche. Santiago: Centro de Estudios Públicos.

Zwicky, A. (1977). On clitics. Bloomington: Indiana University Linguistic Club.

Zwicky, A. (1985). Clitics and particles. Language, 61(2), 283-305.

Zwicky, A., \& Pullum, G. (1983). Cliticization vs. inflection: English n't. Language, 59(3), 502-513. 